\title{
Hepatocellular carcinoma and exposure to hexachlorobenzene: a case report
}

\author{
A SELDÉN,' G JACOBSON, ${ }^{2}$ P BERG, ${ }^{1}$ O AXELSON ${ }^{3}$
}

From the Department of Occupational Medicine, ${ }^{1}$ Örebro Medical Center Hospital, S-701 85 Örebro, Department of Surgery, ${ }^{2}$ University Hospital, S-751 85 Uppsala, and Department of Occupational Medicine, ${ }^{3}$ S-581 85 Linköping, Sweden

In the 1950s several thousand inhabitants of southeastern Turkey were affected by porphyria ("porphyria turcica") caused by consuming wheat seeds treated with hexachlorobenzene (HCB) used as a fungicide. ${ }^{1-3} \mathrm{HCB}$ is a potent animal carcinogen causing thyroid and liver tumours in rodents. ${ }^{46}$ No report of cancer in man from exposure to HCB seems to have been published, ${ }^{7}$ but in view of the potential relation between porphyria and liver cancer, ${ }^{8-9}$ malignancy, particularly of this type, would attract interest in the context of exposure to HCB.

Commercial production of HCB is reported to have ceased in the United States but HCB may still appear, for example, as a contaminant of various pesticides, as a byproduct in chlorinated hydrocarbon synthesis, and in municipal waste incineration..$^{10} \mathrm{~A}$ recent conference on HCB also reflects the worldwide interest and concern regarding this compound in the environment and its potentially adverse effects on man."

The present report presents a case of hepatocellular carcinoma believed to be causally related to occupational exposure to HCB or possibly other chlorinated aromatic hydrocarbons, or both, created from hexachlorethane used in secondary aluminium smelting.

\section{Case report}

The patient, a 65 year old man and a moderate pipe smoker, had had hypertension since his late 40s. His blood pressure has been well controlled on a thiazid and a beta-2-receptor blocker. Otherwise his history was unremarkable.

In the autumn of 1985 he appeared at his local hospital with the complaint of pain under the right costal margin and in the right shoulder. It was obvious that he had an enlarged liver which was further investigated by an ultrasonic scan that showed a large tumour in the right liver lobe and a fine needle biopsy showed malignant cells, probably derived from a hepatocellular carcinoma.

Accepted 25 February 1988
The patient was referred to the University HospitaR in Uppsala. A new liver ultrasonogram showed that the tumour occupied almost the whole right liver lobe, dislocating the median liver vein and the left lobes slightly to the left. A CT scan confirmed these findingsi (fig 1). A liver angiography showed early arterioven ous shunting, typical for hepatocellular carcinoma.

A laparotomy showed no signs of tumour dissemin ation outside the right liver lobe. The findings of the $\vec{r}$ preoperative investigations were confirmed and a right sided lobectomy was performed. The postoperative course was uneventful and the patient was dischargeçe on the 12th postoperative day.

The right liver lobe weighed $2.5 \mathrm{~kg}$ and the tumgut $\overrightarrow{0}$ was $19 \mathrm{~cm}$ at its largest diameter. The tumour showf d typical signs of a highly differentiated hepatocellufa carcinoma (fig 2).

The patient volunteered to take part in a study $\frac{\vec{D}}{5}$ postoperative chemotherapy and he was treated witk intravenous doxorubicin $60 \mathrm{mg} / \mathrm{m}^{2}$ body surface ever third week. He had eight such courses without com $\Rightarrow$ plications except for loss of scalp hair. Sixteen months after the liver resection, his clinical condition wasexcellent and the laboratory test results were com? pletely normal. At this time there was no indication of porphyria, and all screening laboratory test result $\$$ (blood, urine, faeces) were negative in this respect.

\section{Exposure}

The patient had been employed by the same company since the age of 14 . For the first 20 years he was grinder with some exposure to mineral oil mist

From 1955 until retirement in 1981 he was the foreman of a foundry department producing smals items of special or plain steel and of aluminium. From the autumn of 1967 there was an increase in the production of aluminium parts. For this purpose $e_{2}^{\omega}$ there was one minor open melting pot that usuallye contained $10-15(\max 30) \mathrm{kg}$ of metal. For various reasons, including personal interest in the process, the patient intermittently devoted about $25 \%$ of his time to the aluminium smelting, where two to three tablets 


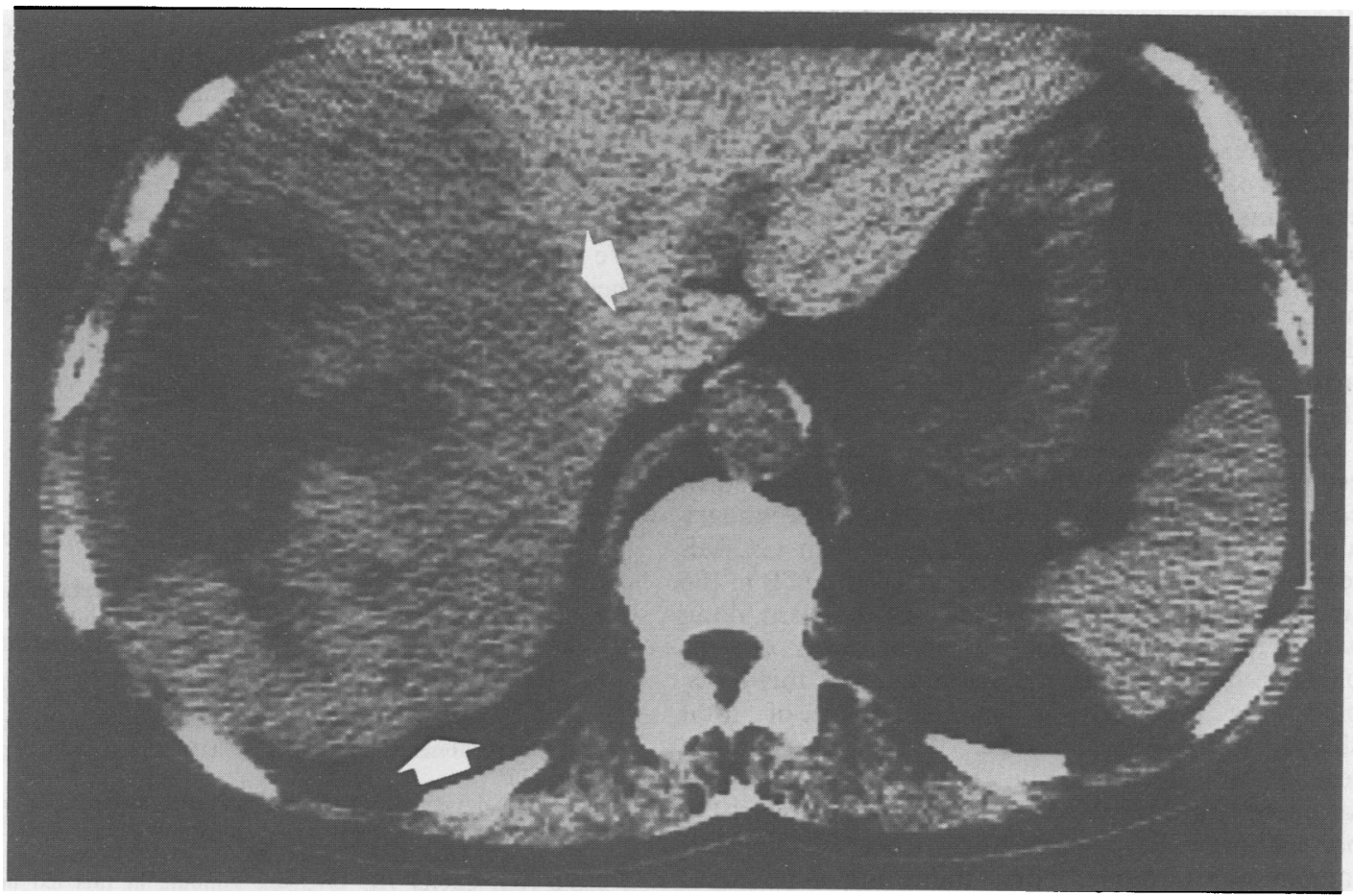

Fig 1 Abdominal CT scan. Tumour tissue constitutes whole right liver lobe (arrows) at this level. Darker area laterally represents necrotic tissue.

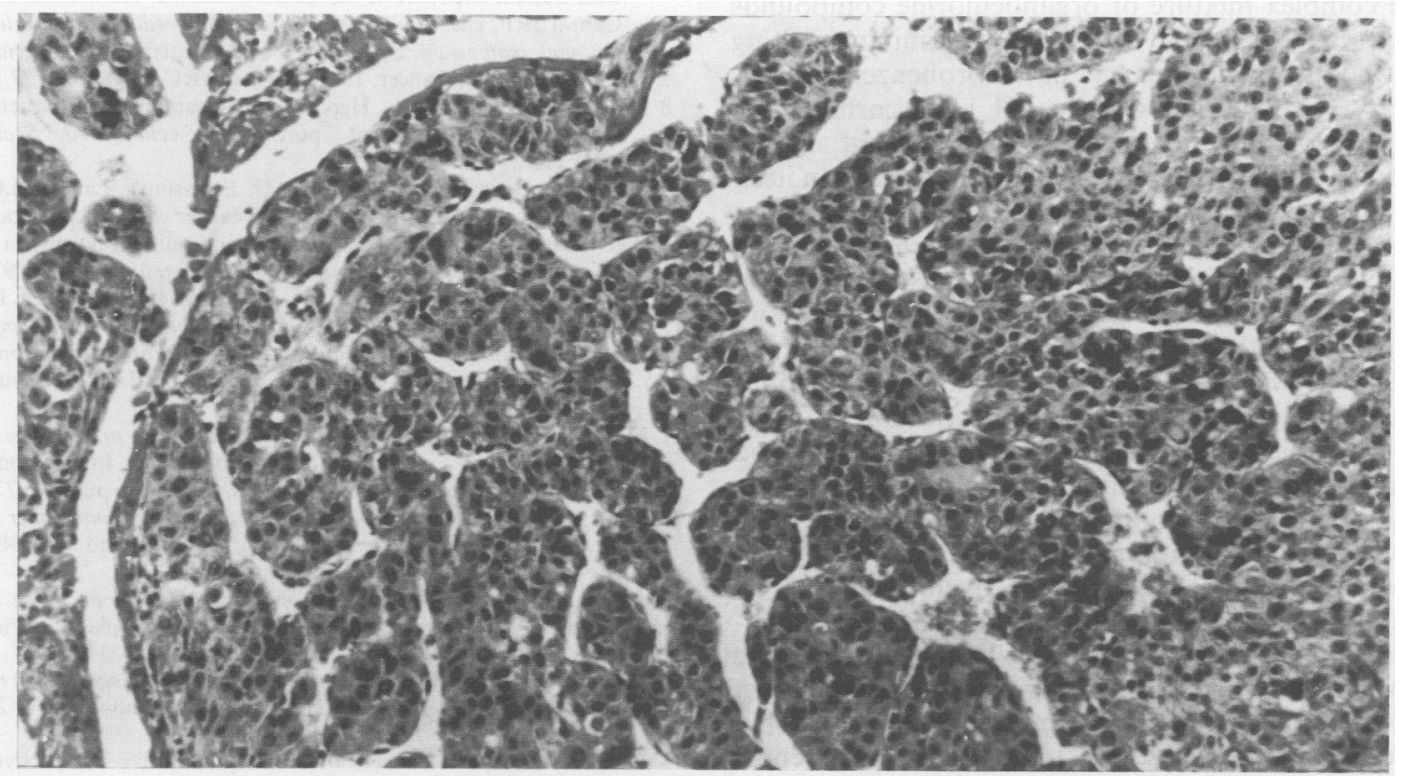

Fig 2 Microscopic appearance of hepatocellular carcinoma $(\times 160)$. 
of a degassing agent containing $30 \%$ hexachloroethane (HCE) were added to each charge to reduce the content of hydrogen. The temperature of the charge was about $700^{\circ} \mathrm{C}$, and the HCE additive caused a boiling reaction forcing the operator to step back because of the heavy chlorine smelling smoke and gas emissions. Adequate local exhaust ventilation was not available and personal protective equipment was not used. The chlorinated emissions, however, were of major concern to the patient and he subsequently developed a vacuum technique for degassing which made the HCE superfluous in 1973. Eight years later the foundry finally closed.

Just before the appearance of this case some interesting studies had been performed at another Swedish company using $\mathrm{HCE}$ for degassing in secondary aluminium smelting. Hence, analyses with GC-MS technique showed high concentrations of HCB in the smoke effluents from various parts of the plant along with a range of other chlorinated benzenes, chlorophenols, dioxins, and dibenzofurans. ${ }^{12}$ At this other plant the estimated annual emissions of total chlorobenzenes at the time of the investigation reached $25-30 \mathrm{~kg}$, mainly $\mathrm{HCB}$. A parallel moss sample, $5 \mathrm{~km}$ downwind from the plant, showed the presence of $\mathrm{HCB}$ (in ppb quantity) whereas an upwind sample was negative, ${ }^{13}$ thus indicating a potential exposure to HCB even to the general population around this type of secondary aluminium smelters.

\section{Discussion}

The complex mixture of organochlorine compounds resulting from the use of $\mathrm{HCE}$ in aluminium smelting showed gross dominance of chlorobenzenes, $96 \%$ being HCB. ${ }^{12}$ Other chlorinated hydrocarbons not subject to monitoring were probably present as well, especially unreacted hexachloroethane, which in itself is a suspected animal carcinogen.$^{14}$ No data, however, .have been available with regard to such exposures.

Given the carcinogenic potential of HCB in animal experiments with the liver as a major target organ we believe that this patient's exposure to HCB and possible exposure to other chlorinated hydrocarbons might have been of aetiological importance for his hepatocellular carcinoma. Moreover, a latency period of about 18 years from first exposure to $\mathrm{HCB}$ to the diagnosis of the tumour seems quite reasonable for a solid, highly differentiated malignant tumour.

Some consideration should be given to alcohol, an established determinant for hepatocellular carcinoma. ${ }^{15}$ The patient admitted regular but moderate drinking at weekends but there was no evidence of alcohol abuse. Since synergism between alcohol and acute carbon tetrachloride toxicity has been reported, ${ }^{16}$ there might be a similar mechanism of interaction with regard to $\mathrm{HCB}$ and structurally related chlorinated hydrocarbons.

\section{Seldén, Jacobson, Berg, Axelson}

In conclusion, this case of hepatocellular carcinoma in a man with exposure to $\mathrm{HCB}$ and other chlorinated compounds in secondary aluminium smelting suggeșts a possible aetiology of liver cancer and perhaps other malignancies. Further research is warranted to clarfy the relation.

We thank Dr Mattias Volmerstedt and his staff their support in this investigation and Margaret $\mathbb{B a}$ Sandin for preparing the manuscript.

Requests for reprints to: Dr A Seldén.

\section{References}

1 Schmid R. Cutaneous porphyria in Turkey. $N$ Engl $J$ Med 1960;263:397-8.

2 Cam C, Nigogosyan G. Acquired toxic porphyria cutanea tarda due to hexachlorobenzene. JAMA 1963;183:88-91.

3 Gocmen A, Peters HA, Cripps DJ, Morris CR, Dogramaciő Porphyria turcica: hexachlorobenzene-induced porphyria. $\mathbf{m}$ : Morris CR, Cabral JRP, eds. Hexachlorobenzene: proceedings of an international symposium, Lyon, 1985. Lyon: Internationa Agency for Research on Cancer, 1986:567-73. (IARC sci puti No 77.)

4 International Agency for Research on Cancer. Monographs on evaluation of the carcinogenic risk of chemicals to humans. 20. Hexachlorobenzene. Lyon: IARC, 1979: 155-78.

5 Smith AG, Cabral JR. Liver-cell tumours in rats fed hex: chlorobenzene. Cancer Lett 1980;11:169-72.

6 Smith AG, Francis JE, Dinsdale D, Manson MM, Cabragg Hepatocarcinogenicity of hexachlorobenzene in rats and the s. difference in hepatic iron status and development of porphr. Carcinogenesis 1985;6:631-6.

7 Axelson 0 . A review of porphyria and cancer and the missing ligh with human exposure to hexachlorobenzene. In: Morris C Cabral JRP, eds. Hexachlorobenzene: proceedings of an int:national symposium, Lyon, 1985. Lyon: International Ageney for Research on Cancer, 1986:585-9. (IARC sci publ No 77 $\Phi$

8 Lithner F, Wetterberg L. Hepatocellular carcinoma in patients with acute intermittent porphyria. Acta Med Scañid 1984;215:271-4.

9 Hardell L, Bengtsson NO, Jonsson U, Eriksson S, Larsson LiG. Aetiological aspects on primary liver cancer with special regक्fd to alcohol, organic solvents and acute intermittent porphyrias an epidemiological investigation. Br J Cancer 1984;50:389-97.

10 Tobin P. Known and potential sources of hexachlorobenzene. In: Morris CR, Cabral JRP, eds. Hexachlorobenzene: proceedings of an international symposium, Lyon, 1985. Lyon: Internatiogal Agency for Research on Cancer 1986:3-11. (IARC sci püb No 77.)

11 Morris CR, Cabral JRP, eds. Hexachlorobenzene: proceedings $\frac{\mathrm{O}}{7} f$ an international symposium, Lyon, 1985. Lyon: Internatiofal Agency for Research on Cancer, 1986. (IARC sci publ No

12 Månsson L, Plachetka H. Aluminiumsmältverket. Emissioner $\overline{\mathrm{ga}^{v}}$ klorerade organiska ämnen. Enköping: Metlab Miljö AB, $19 \$ 0$. (Report No KEM-256.) (In Swedish.)

13 Jensen S. Användning av mossa och/eller lav för monitoring Q্̣v luftburna föroreningar. Stockholm: Wallenberglaborator 1986. (In Swedish.) (Report under contract No 5314236-0.) 0

14 International Agency for Research on Cancer. Monographs on the evaluation of carcinogenic risk of chemicals to humans. Vol (2). Hexachloroethane. Lyon: IARC, 1979:467-76.

15 Popper H. Hepatic cancers in man: quantitative perspectives. Environ Res 1979;19:482-94.

16 Hasumura Y, Teschke R, Lieber CS. Increased carbon tetochloride hepatotoxicity, and its mechanism, after chroficic ethanol consumption. Gastroenterology 1974;66:415-22. 